\title{
Management Strategy Islamic Religious Education Teacher in the Development of Student Morality
}

\author{
Abdul Rauf ${ }^{1 *}$ \\ ${ }^{1} S M P$ Negeri 9 OKU, South of Sumatera, Indonesia \\ *Corresponding author. Email: raufabdul232@gmail.com

\begin{abstract}
This research is motivated by a phenomenon of student delinquency that has lately become increasingly worrying, such as: inter-student brawls, free association among adolescents, drug abuse and so on, from which teachers, especially Islamic religious education teachers have a duty and role to improve student Islamic behavior. The results of this paper indicate that: 1) efforts made by Islamic Religious Education teachers; 2) method of Coaching student morals carried out by teachers; 3) supporting factors in moral coaching, and 4) factors that inhibit moral development.
\end{abstract}

Keywords: Management Strategy, Religious Education, Student Morality

\section{INTRODUCTION}

Often, we see on television a lot of news about moral damage among teenagers. On the other hand, not a few of the younger generation failed to display commendable morality in accordance with the expectations of parents. So, to overcome all moral problems above must be done coaching early.

Talking about moral coaching is the same as talking about the purpose of education, because there are many opinions of experts who say that the purpose of education is moral coaching. Education is any planned effort to influence others whether individuals, groups, or communities so that they do what education actors expect [1].

Education is the most significant predictor for the growth of a nation [2]. Education is very important in this day and age education can shape a person into quality and have a broad view of the future to achieve the ideals expected and able to adapt quickly and precisely in various environments. Because education itself motivates ourselves to be better in all aspects of life. Education is a very important human need, because education has a duty to prepare Human Resources for the development and progress of the nation [3]. Education is a conscious effort made by human beings through guidance, teaching, and training activities, which take place in schools and outside schools. Education will be perfect when accompanied by religious education. Indonesian human resources do not yet have a good education to become a competent workforce and be able to compete [4]. This standard's aim is to ensure the quality of national education in order to educate the nation and form the character and civilization of a dignified nation [5].

Religious education in this case is Islamic education, is all efforts to maintain and develop human nature towards the formation of a whole human being in accordance with Islamic norms [6].

Religion also regulates man's relationship with God, human relationship with man, human relationship with nature and human relationship with him, balance and harmony in life, both as a person and as a member of society in achieving outward progress and happiness bathiniah. Therefore, religious education is the most important part of education to preserve aspects of religious attitudes and values. Religious education must also have a purpose that is in the form of three aspects, namely aspects of faith, science and charity that are inseparable joints. In addition, an educator should not only teach science to his students but also morals.

The increasingly modern and pluralistic life of society has given a variety of colors in various facets. The reality of modernization has pervaded almost all religious values that should have been reflected in good behavior. The change is not only in the field of technology, but more dangerous is the destruction of 
morals, morals, ethics and human behavior, which consequently triggers the destruction of this nation. The layers of society that are very easily affected from the outside are teenagers, because they are experiencing emotional shock due to the changes and growth they go through [7].

The teacher plays a very important and strategic role because he is responsible for directing his students in terms of mastery of knowledge and its application in life and in instilling and providing good tauladan to the students in relation. A teacher is not only tasked to transfer science, but much heavier is to direct and shape the behavior or personality of the student

\section{METHODS}

The research done requires the right method to get the data in accordance with the research to be done. Methodology is a determining factor for the merits of writing scientific papers [7]. As for this research, this research uses a qualitative approach, this is in accordance with the theme and title of the research proposed by researchers.

The type of research used in this research is a type of qualitative descriptive research with the reason because the data obtained by researchers can describe in the research.

Qualitative descriptive is a research method that intends to create sensing (description) of situations and events [8]. To determine the subjects in this study, researchers chose purposive sampling techniques and Snowball Sampling. Purposive methods sampling is a sampling technique of data sources with certain considerations [8]. This particular consideration, for example the person who is considered to know best about what we expect, or perhaps he or she as the ruler so that it will make it easier for researchers to explore the objects / social situations studied.

In purpose, sampling techniques researchers choose research subjects with the aim to determine key information that are in accordance with the focus of research conducted deliberately without contrived to obtain its strength. As for adding credibility to the data, researchers also use snowball sampling techniques which aim to develop information. The snowball sampling technique itself is a data source sampling technique, which at first amounts to a little bit of being large [9]. This is done because from the small number of data sources that have not been able to provide satisfactory data, then look for others who can be used as data sources.

The subjects in this study were Islamic Religious Education teachers, namely Marlini's mother and Erika as Counseling Guidance teachers. Next will look for other data sources to provide the data needed. Thus, the number of sample data sources will be greater, such as snowballs rolling, long to be large.

\section{RESULTS AND DISCUSSION}

\section{1) Efforts of Islamic Education Teachers in Building Morals}

As we know, teachers are professional educators in their field as the main task of educating, training, assessing, and evaluating both in the scope of formal and non-formal education. A professional teacher then he will know how to apply and transfer the knowledge they have to the students he/she is studying. In addition, teachers are also one of the humane components in the process of teaching and learning activities which participate in shaping human resources into a professional person.

However, the function of teachers is not only as stated based on the explanation above but the role of teachers is also very important in printing the younger generation (learners) into human beings who are virtuous and noble as taught by the Prophet as role models and suritauladan who have akhlakul karimah.

This is the role of a teacher, especially islamic education teachers who are required to foster their students to have good character and character [10]

\section{2) Methods Used by Teachers of Islamic Religious Education in Fostering Morality}

When we talk about methods, we can't be separated from the way that teachers do in fostering their students to have good character. In addition to behaving well, a teacher must also have various ways to teach, instill, and maintain good character to all students.

By using the right methods, anything that has been given by teachers, especially in fostering morals can be easily absorbed and imitated by students well. The use of appropriate methods will determine the effectiveness and efficiency in the process of coaching students' morals. As a teacher, we need to know the techniques /methods in the development of students' morality. By using these methods, a teacher is expected to be an example and role model for his students so that the goal in printing students who have karimah can be achieved more easily.

\section{3) Factors That the Teacher of Islamic Religious Education in Building Morality}

When we talk about morality, certainly not apart from the term ethics. In fostering and educating students can't be separated from the duties and responsibilities of both parents and the school, namely teachers as parents. In addition, in the process of implementing it, the role of teachers, especially teachers of Islamic Religious Education are very necessary. However, the role of teachers alone is not enough in fostering and educating students to be good.

School facilities are the most important factor in fostering student morale. another factor that is 
supporting is the presence of educators who are skilled in their field in fostering the morality of students, especially teachers of Islamic Religious Education. the role and support of parents who always support their children, have the vision and mission and objectives of the school that prioritizes religious issues, has professional teachers and teachers, is reliable in their field and has good character, and many other supporting factors.

\section{4) Factors That Hinder Teachers of Islamic Religious Education in Fostering Morality}

Morality is one of the most important things in everyday life is no exception for children as the next generation of the nation in the future. What happens if the next generation does not have good character, because a good nation is a nation that upholds norms, ethics, and morals in order to create a virtuous generation.

We can see the current condition that our nation is experiencing a moral crisis caused by a lack of understanding and implementation, as well as the development of its own morals. In general, moral development, especially for children, is very important. Therefore, all resources and efforts are always made to foster morality starting from the family, school, and community environment.

In fostering and educating students in school is not easy such as turning the palm because in its implementation will face various obstacles and obstacles. Therefore, the struggle in fostering student morality will not always run smoothly even often we will often find various student problems.

In the process of coaching students' morality there are several inhibitory factors that are very influential in the development of student morals. The main factor in the problem starts from the difference in the student's own background. In addition, schools also have obstacles both internally and externally. This is where the role of teachers in overcoming these two obstacles so that teachers can overcome the problem of poor student morality.

Internal factors are factors that come from within. This means that the pest is emerging from the school environment itself that there is no awareness from within the student itself but that the act will be done by the student if the student is ordered. The next internal factor is the lack of availability of both school facilities and infrastructure

The external factors include various things, such as family environmental factors. The family environment is often the main obstacle. Because

Speaking of family environment, this environment is the first time, children will get education, direction, guidance, foster care, habituation, coaching, and training. The family is not only a place to raise and raise children, but also a place where children live and get an education for the first time before the school environment and society. What it obtains in family life will be the basis and foundation in the development of later lives.

However, teachers sometimes always find obstacles in this problem. This is probably what will be a challenge that we face as teachers of Islamic Religious Education in printing students who are good practice. Differences in coaching patterns, education and foster care patterns in different family environments will encourage us to solve the problem.

Another obstacle is the lack of religious education background of parents in guiding, educating, and fostering their children. If the background of religious education is low, it will also be low planting of religion to his children. In addition, other factors such as a minimal economy which should require them to work without knowing the time. As a result, the child becomes less attentive so they seek their own pleasure by playing with their friends without parental supervision.

Parents are role models for every child. What the parents do will be treated and imitated indirectly by the child.

The role of parents is very large in guiding, educating, and nurturing their children to make noble human beings. How can a child have good character if in a family environment the child rarely gets attention or even affection from both parents, in addition, economic factors that keep parents busy with their work without thinking about the continuity of children's own behavior.

The next problem is the environmental factor of the community. The influence of this environment is very large for the development of the religious soul both from a positive and negative point of view. The association of students outside the school is very influential for example in the association. Because if the student is wrong in stepping and choosing a bad association, it will automatically affect the mental and morals of the student itself. The amount of influence from outside is inseparable from the norms and habits carried out by students.

The conclusion of the explanation above that the tendency of deviation and the appearance of poor morality are mostly from environmental factors, especially in choosing the wrong association that make students tend to deviate and have no morals.

Then the last factor that becomes an obstacle for teachers in fostering student morality is the current globalization and the advancement of modern technology. Speaking of this issue of course we can never be separated from the advances in the use of technology that we now feel. 
Technological advances in the globalization era now a change that requires us to be easier in doing everything. However, from this factor can also cause two sides both positive and negative side depending on one's own in using the sophistication of technology as it is today. In this case we often find a lot of abuse of the use of technology that makes children become deviant behavior is no exception for students.

\section{CONCLUSION}

From the research, can be conclude: 1) the teacher's strategy in fostering akhlakul karimah, among others, by applying discipline to teachers, staff, students, and all elements involved in the school, and 2) the methods used by Islamic Religious Education teachers in fostering student morality include supervision methods, methods of nudity, and mentoring methods

\section{ACKNOWLEDGMENTS}

Our deepest gratitude goes to Teachers in SMP Negeri 9 OKU, Chancellor of Palembang PGRI University, Director of the Postgraduate Program of PGRI Palembang University and the Education Management Study Program of PGRI Palembang University, who have supported us in doing this extraordinary thing. This project is funded independently. We also want to thank our Education Management friends who helped us a lot in a short time frame to complete this project.

\section{REFERENCES}

[1] Notoatmodjo, S. (2003). Pendidikan dan perilaku Kesehatan [Health education and behavior]. Jakarta: PT Rineka Cipta

[2] Asvio, N., Yamin, M., \& Risnita. (2019). Influence of Leadership Style, Emotional Intelligence and Job Satisfaction toward Organizational Commitment (Survey at SMA Muhammadiyah South Sumatera). International Journal of Scientific \& Technology Research 8 (8).

[3] Handayani, D. O., Kristiawan, M., \& Destiniar. (2020). Education and Training for Strengthening Principal to Effective Schools. International Journal of Progressive Sciences and Technologies (IJPSAT), 22(1), 321-326.

[4] Budiyono, Lian, B., \& Fitria, H. (2020). The Influence of Principal Supervision and Organizational Climate toward Teacher's Performance. Electronic Research Journal of Social Sciences and Humanities Vol 2: Issue II.

[5] Irmayani, H., Wardiah, D., \& Kristiawan, M. (2018). The Strategy of SD Pusri in Improving Educational Quality. International Journal of Scientific \& Technology Research Volume 7, Issue 7, July.
[6] Suryabrata, S. (2008). Metode Penelitian [Research Methods]. Jakarta: Raja Grafindo Persada.

[7] Achmadi. (2005). Ideologi Pendidikan Islam: Paradigma Humanisme Teosentris [Islamic Education Ideology: Theocentric Humanism Paradigm]. Yogyakarta: Pustaka Pelajar.

[8] Muttaqin, K., \& Rahmadoni, J. (2020). Analysis and Design of File Security System AES (Advanced Encryption Standard) Cryptography Based. Journal of Applied Engineering and Technological Science (JAETS), 1(2), 113-123. https://doi.org/10.37385/jaets.v1i2.78

[9] Daradjat (1976). Pembinaan Remaja [Youth Coaching]. Jakarta: Bulan Bintang.

[10] Sugiyono. (2014). Metode Penelitian Kuantitatif Kualitatif dan $R \& D$ [Qualitative and Quantitative Research Methods and $R$ \& D]. Bandung: Alfabeta. 